Syntax Literate: Jurnal Ilmiah Indonesia p-ISSN: 2541-0849

e-ISSN: 2548-1398

Vol. 6, No. 12, Desember 2021

\title{
EFEKTIVITAS EKSTRAK ETANOL DAUN RAMBAI (BACCAUREA DULKIS MUELL.ARG) TERHADAP PENYEMBUHAN LUKA SAYAT DAN EKSPRESI TGF-B1 PADA TIKUS PUTIH JANTAN
}

\section{Zulfiawan, Kamaluddin, Irsan Saleh, Theodarus, Salni, fatmawati}

Magister of Biomedical Science, Medical Faculty, Universitas Sriwijaya (UNSRI)

Palembang, Indonesia

Email: zulfiawan2285@gmail.com, totongkamaluddin@unsri.ac.id, irsan_saleh_hasani@yahoo.com, theodarusparulian@yahoo.com, salnibasir@yahoo.com, fatmawati.karim@fk.unsri.ac.id

\begin{abstract}
Abstrak
Daun rambai Baccaurea dulkis Muell. Arg. merupakan salah satu tumbuhan khas kalimatan tengah dan kalimatan selatan yang daunnya secara empiris dapat digunakan masyarakat sebagai obat luka serta penghilang bekas luka pada kulit. Tujuan dari penelitian ini untuk menilai efektivitas ekstrak etanol daun rambai (Baccaurea dulkis Muell. Arg) Penelitian ini bertujuan untuk menilai efek topikal ekstrak daun rambai Baccaurea dulkis Muell. Arg. Arg terhadap kadar TGF- $\beta 1$ pada fase inflamasi akut luka sayat tikus (Rattus norvegicus) Jantan galur Wister. Penelitian ini merupakan suatu penelitian eksperimental laboratorium in vivo, dengan metode pre and post test only pada tikus Wister. Penelitian ini dilaksanakan dari bulan Juli sampai dengan oktober tahun 2020. Pelaksanaan penelitian dilakukan di Laboratorium Biomolekuler dan Animal House Fakultas Kedokteran Universitas Sriwijaya Palembang. Subjek penelitan berupa tikus putih wister dengan jenis kelamin jantan yang dibagi ke dalam 5 (lima) kelompok perlakuan secara random, yaitu kelompok kontrol negatif (aquades), kelompok kontrol positif (povidone iodine), kelompok ekstrak daun rambai konsentrasi 1\%, kelompok ekstrak daun rambai $2 \%$ dan kelompok kelompok konsentrasi $4 \%$. Data yang diperoleh kemudian dianalisis secara statistic menggunakan SPSS versi 19 dengan Uji uji parametrik, uji $\mathrm{T}$ berpasangan (paired $\mathrm{t}$-test) uji $\mathrm{T}$ tidak berpasangan (Independen t-test) atau Mann Whitney. Hasil penelitian menunjukan waktu penyembuhan luka sayat tikus putih jantan pada hari ke 3 konsentrasi ekstrak etanol daun Baccaurea dulkis Muell.Arg. 2\% dan 4\% tidak berbeda bermakna dengan efektivitas Povidone Iodine dan pemberian daun rambai pada tikus luka sayat dengan Povidone Iodine dilihat dari kadar rerata TGF- $\beta 1$ pada penyembuhan luka. Tidak terdapat perbedaan yang bermakna kadar rerata TGF- $\beta 1$ pada tikus luka sayat dengan penggunaan daun rambai dengan Povidone Iodine pada penyembuhan luka.
\end{abstract}

Kata Kunci: daun rambai; luka sayat; TGF- $\beta 1$
Abstract
Rambai Baccaurea dulkis Muell leaves. Arg. It is one of the typical plants of middle sentences and southern sentences whose leaves can be empirically used by

$\begin{array}{ll}\text { How to cite: } & \text { Zulfiawan, Kamaluddin, Irsan Saleh, Theodarus, Salni, fatmawati (2021) Efektivitas Ekstrak Etanol Daun } \\ & \text { Rambai (Baccaurea Dulkis Muell.Arg) Terhadap Penyembuhan Luka Sayat Dan Ekspresi Tgf-B1 Pada } \\ & \text { Tikus Puth Jantan. Syntax Literate: Jurnal Ilmiah Indonesia, 6(12). http://dx.doi.org/10.36418/syntax- } \\ & \text { literate.v6i12.5192 } \\ \text { E-ISSN: } & 2548-1398 \\ \text { Published by: } & \text { Ridwan Institute }\end{array}$


the community as a wound medicine and scar removal on the skin. The purpose of this study was to assess the effectiveness of rambai leaf ethanol extract (Baccaurea dulkis Muell. Arg) This study aims to assess the topical effects of baccaurea dulkis muell rambai leaf extract. Arg. Arg against TGF- $\beta 1$ levels in the acute inflammatory phase of the rat's sores (Rattus norvegicus) Male Wister strain. This study is an experimental laboratory study in vivo, with a pre and post test only method in Wister mice. The study was conducted from July to October 2020. The research was conducted at the Biomolecular Laboratory and Animal House of the Faculty of Medicine, Sriwijaya Palembang University. The subjects of the study were wister white mice with male sex divided into 5 (five) random treatment groups, namely the negative control group (aquades), the positive control group (povidoneiodine), the rambai leaf extract group with a concentration of $1 \%$, the rambai leaf extract group $2 \%$ and the concentration group $4 \%$. The data obtained was then analyzed statistically using SPSS version 19 with parametric test, paired t-test or Mann Whitney. The results showed that the healing time of male white rats' wounds on day 3 of the concentration of ethanol extract of Baccaurea dulkis Muell.Arg. 2\% and 4\% was not meaningful with the effectiveness of Povidone Iodine and the administration of rambai leaves in mice with Povidone Iodine. Seen from the average level of TGF- $\beta 1$ in wound healing. There was no significant difference in the average rate of TGF- $\beta 1$ in mice with the use of rambai leaves with Povidone Iodine in wound healing.

Keywords: rambai leaves; sores; TGF- $\beta 1$

Received: 2021-11-20; Accepted: 2021-12-05; Published: 2021-12-20

\section{Pendahuluan}

Luka merupakan salah satu proses kerusakan atau hilangnya komponen jaringan yang terjadi mengenai bagian tubuh tertentu, jenis luka salah satunya adalah luka sayat, dimana penyebab cidera trauma, baru, mendadak dan cepat penyembuhannya, dapat terjadi akibat berupa pisau dan benda tajam. Sehingga luka dapat digambarkan sebagai gangguan dalam kontinuitas sel-sel lalu diikuti dengan penyembuahan yang merupakan pemulihan kontinuitas (Kurniawaty, Farmitali, Rahmanisa, \& Andriani, 2018). Berdasarkan penyebabnya luka sayat (Vulnus Scisum) adalah salah satu jenis trauma yang pelindung mudah terjadi luka baik itu ringan maupun berat. Proses penyembuhan dari secara normal dapat terjadi menggunakan bantuan atau secara alami, selain itu penyembuhan luka juga dapat terhambat akibat banyak faktor yang bersifat lokal atau sistemik (Monaco \& Lawrence, 2003). Sebagian besar masyarakat tidak menyadari bahaya luka. Masyarakat cenderung memilih untuk membiarkan luka, memberikan pengobatan seadanya dengan mencuci luka atau memberikan obat antiseptik seperti Povidone iodine yang memiliki efek antimikroba masih menjadi perdebatan karena menimbulkan efek toksik pada penelitian in vitro tingkat sel, sehingga diperlukan alternatife pengobatan yang lain (Muhammad, 2005). Sering terjadi kulit sebagai organ tubuh yang terletak paling luar dan terbesar serta fungsinya sebagai Efek samping dari povidone iodine yaitu hipersensitivitas, iritasi lokal dan hipotiroidisme. Penggunaan 
obat-obatan untuk penyembuhan luka dapat dilakukan dengan berbagai macam cara, salah satunya adalah penggunaan obat tradisional (Tanjung \& Kameubun, 2009). Obat tradisional adalah media pengobatan dengan menggunakan bahan-bahan alamiah dari tumbuhan (Kumala Sari, 2006). Tumbuhan obat yang dapat menyembuhkan luka sayat antara lain daun murbei, daun pule pandak, daun tembelekan, daun sendok dan daun sambiloto (Dalimartha, 2008). Salah satu tumbuhan yang bisa dijadikan sebagai tumbuhan obat adalah rambai (Baccaurea dulkis Muell. Arg). Secara tradisional daun rambai merupakan salah satu tumbuhan khas kalimatan khususnya kalimatan selatan yang daunnya secara empiris dapat digunakan masyarakat sebagai obat luka serta penghilang bekas luka pada kulit (Handayani, Hana, Feronika Heppy Sriherfyna, 2015) Genus Baccaurea dulkis Muell. Arg. Pada umumnya mengandung sejumlah senyawa metabolit sekunder seperti saponin, flavonoid dan tannin pada buah maupun daunnya (Sogandi, 2017). Di kalimantan tengah buah maupun daun ramabai mempunyai banyak manfaat untuk berbagai pengobatatan seperti penyakit cacar, obat diare dan pengobatan dalam penyembuhan luka memar dikulit. Daun rambai juga mempunyai kandungan seperti tanin, flavonoid dan saponin (Sogandi, 2017). Penelitian (Prasetyaningrum, 2015) menyebutkan bahwa ekstrak daun Baccaurea dulkis Muell. Arg. mengandung zat aktif antara lain flavonoid, glikosida, kuinon, tannin, triterpenoid dan steroid. Menurut (Hidayatullah, 2016) menyatakan bahwa senyawa yang berperan dalam proses penyembuhan luka adalah senyawa flavonoid dan tannin. Senyawa flavonoid memiliki efek meningkatkan kecepatan kontraksi luka, kecepatan pembentukan kolagen dan waktu epitelisasi yang lebih singkat. Tannin mempunyai daya antiseptik yaitu mencegah kerusakan yang disebabkan oleh bakteri dan jamur. Dalam berbagai penelitian ekstrak tanaman yang mengandung flavonoid terbukti memiliki pengaruh dalam proses penyembuhan luka. Dalam penelitian yang lebih luas terhadap penggunaan klinis, fungsi dan manfaat flavonoid sangat beragam dalam berbagai aplikasi pengobatan. Flavonoid memiliki efek sebagai antiskleroti kanti inflamasi, antitrombogenik, antitumor, antiosteoporosis, antibakteri dan antivirus. Aktivitas flavonoid dalam proses penyembuhan luka adalah dengan meningkatnya aktivitas kontraksi dan epitelisasi serta meningkatnya pembentukan jaringan granuloma (Wang, Avula, Nanayakkara, Zhao, \& Khan, 2013) Saponin merupakan metabolit sekunder dari tanaman yang termasuk dalam golongan terpenoid dan dalam klasifikasi jenis triterpenoid.

Pada proses jalur pengaktifan TGF- $\beta$, saponin dapat merangsang pembentukan, sekresi, dan aktivasi TGF- $\beta 1$ pada fibroblast. Efek saponin juga mengubah ekspresi reseptor TGF- $\beta$ dan sistem transduksi sinyal post- receptor (Kanzaki, Morisaki, Shiina, \& Saito, 1998). Proses dalam penyembuhan luka yaitu kolagen disamping sel epitel. Fibroblas dan sel yang bertanggung jawab untuk sintesis kolagen. Fisiologi penyembuhan luka secara alami akan mengalami fase-fase seperti sejak terjadinya luka. Setelah terjadinya luka, pembuluh darah yang putus mengalami konstriksi dan retraksi disertai reaksi hemostasis karena agregasi trombosit yang bersama jala fibrin membekukan darah. Komponen hemostasis ini akan melepaskan dan mengaktifkan sitokin yang meliputi Epidermal Growth Factor (EGF), Insulin- like Growth Factor 
(IGF), Plateled-derived Growth Factor (PDGF) dan Transforming Growth Factor beta (TGF- $\beta$ ) yang berperan untuk terjadinya kemotaksis netrofil, makrofag, mast sel, sel endotelial dan fibroblas. Keadaan ini disebut fase inflamasi. Pada fase ini terjadi vasodilatasi dan akumulasi lekosit Polymorphonuclear (PMN). Agregat trombosit akan mengeluarkan mediator inflamasi Transforming Growth Factor beta 1 (TGF $\beta 1$ ) yang juga dikeluarkan oleh makrofag. Adanya TGF $\beta 1$ akan mengaktivasi fibroblas untuk mensintesis kolagen (Perdanakusuma, 2007). Pada fase inflamasi terjadi proses angiogenesis, diman.

\section{Metode Penelitian}

Metode ini merupakan studi eksperimental dengan menggunakan rancangan penelitian post test only control design dimana pengukuran hanya dilakukan setelah perlakuan selesai. Penelitian ini dilaksanakan pada bulan Juli- Oktober 2020. Populasi penelitian ini adalah tikus (Rattus norvegicus) Jantan galur Wister. Sampel tikus yang akan digunakan berusia 2-3 bulan dengan berat badan 150-250 gram berjenis jantan pembuluh-pembuluh darah yang baru mulai tumbuh dalam luka injuri dan sangat penting peranannya oksigen dalam fase proliferasi. Fibroblas dan sel endothelial mengubah molekular dan larut dengan superoxide yang merupakan senyawa penting dalam resistensi terhadap infeksi maupun pemberian insyarat oxidative dalam menstimulasi produksi growth factor lebih lanjut. Dalam proses inflamasi adalah suatu perlawanan terhadap infeksi dan sebagai jembatan antara jaringan yang mengalami injury dan untuk pertumbuhan sel-sel baru (Sumara, 2017). Penemuan senyawa obat baru melewati beberapa tahap uji. Salah satu uji yang harus dilakukan adalah uji praklinik. Uji praklinik bermanfaat untuk mendeteksi dan mencegah terjadinya bahaya agar tidak memasuki lingkungan masyarakat. Kebanyakan uji praklinik melibatkan penggunaan hewan, seperti mencit, ayam, monyet, kelinci dan tikus percobaan (Kee \& Hayes, 1996). Penelitian terhadap tumbuhan Baccaurea dulkis Muell. Arg ini hanya dibatasi pada daun dengan menggunakan metode ekstraksi yaitu maserasi. Penelitian mengenai pemanfaatan ekstrak etanol daun Baccaurea dulkis Muell. Arg terhadap penyembuhan luka sayat belum pernah dilakukan. Oleh karena itu, peneliti tertarik untuk melakukan penelitian mengenai efektivitas ekstrak etanol daun Baccaurea dulkis Muell. Arg terhadap penyembuhan luka sayat dan ekspresi TGF- $\beta 1$ pada tikus putih jantan.

Tikus uji akan didapatkan dari Bogor. Sebelum diberi perlakuan, Aklimatisasi hewan selama 7 hari di Animal House FK Unsri Palembang. Penggunan hewan pada penelitian ini telah disesuaikan dengan aturan etika penelitian yang diatur dalam deklarasi Helsinski dan telah memperoleh "Ethical Clearance" dari Komite Etik Penelitian Fakultas Kedokteran Universitas Sriwijaya, Palembang.

Pada penelitian ini, jumlah sampel untuk tiap kelompok ditentukan sebanyak 5 ekor tikus berjenis kelamin jantan $(n>4)$, dan jumlah kelompok tikus ada 5 sehingga penelitian ini membutuhkan 30 tikus dari populasi yang ada, ditempatkan dalam kandang dan masing- masing tikus diperlakukan dengan baik, diberi makan dan minum 
sesuai dengan kebutuhan. Pada penelitian ini, Kemudian dilakukan anestesi dengan ketamine $(20 \mathrm{mg} / \mathrm{kg} \mathrm{BB})$ secara intraperitonial. Setelah itu satu persatu tikus dilukai dengan menggunakan scalpel steril, panjang luka sayatan $2 \mathrm{~cm}$ dengan kedalaman 0,5 $\mathrm{cm}$ sejajar dengan os vertebrata, berjarak $5 \mathrm{~cm}$ dari telinga kiri dan kanan. Pengolesan area luka dengan menggunakan kapas steril setiap 2 kali sehari. Semua tikus diperiksa penyembuhan luas luka pada hari ke 3, 7 dan 14 menggunakan jangka sorong, kemudian pada hari ke 14 diambil sampel dari data kemudian di analisis menggunakan uji homogenitas data levene's test of varians untuk mengetahui dua atau lebih kelompok penelitian memiliki varian yang sama atau tidak. Jika hasil uji normalitas dan homogenitas normal menggunakan uji parametrik data hasil pengukuran ekspresi TGF$\beta 1$ pada tikus sebelum dan sesudah perlakuan dianalisis menggunakan uji T.

\section{Hasil dan Pembahasan}

\section{A. Hasil Penelitian}

Hasil Penelitian ini bertujuan untuk mengetahui efektivitas efektivitas ekstrak daun Daun rambai Baccaurea dulkis Muell. Arg terhadap penyembuhan luka sayat dan ekspresi TGF- $\beta 1$ Sampel pada penelitian ini yaitu 30 ekor tikus Wistar jantan dibagi menjadi 5 kelompok dengan masing- masing kelompok terdiri dari 6 sampel. Kontrol negatif diberikan Aquades, kelompok II diberikan ekstrak rambai 1\%, kelompok III diberikan ekstrak binahong 2\%, kelompok IV diberikan ekstrak binahong 4\% dan Kontrol positif diberikan salep Povidone iodine. Ekstraksi Simplisia Daun Daun rambai Baccaurea dulkis Muell. Hasil ekstraksi simplisia atau serbuk halus daun Daun rambai Baccaurea dulkis Muell. sebanyak 400 gram setelah dilakukan ekstraks maka diperoleh berat ekstrak kental sebanyak 30 gram. Setelah diperoleh ekstrak etanol daun rambai selanjutnya dilakukan pembuatan salep ekstrak binahong masingmasing dosis yaitu $1 \%, 2 \%$ dan $4 \%$.

Hasil Uji Fitokimia Uji Fitokimia Daun rambai Baccaurea dulkis Muell. Arg hanya diuji kandungan fitokimianya di Laboratorium biokimia yaitu golongan senyawa flavonoid, tannin dan saponin. Hasil uji fitokimia dapat dilihat pada tabel dan gambar di bawah ini: Tabel 1. Hasil uji fitokimia dapat dilihat pada tabel dan gambar di bawah ini:

Tabel 1

\section{Hasil Screening Fitokimia Ekstrak}

\begin{tabular}{|c|c|c|}
\hline Senyawa MetabolitSekunder & Hasil & Keterangan \\
\hline$\overline{\text { Saponin }}$ & + & Terbentuk busa $>1$ Jam dan tinggi busa $1 \mathrm{~cm}$ \\
\hline Tanin & + & $\begin{array}{l}\text { Terbentuk warna Biru } \\
\text { kehitaman }\end{array}$ \\
\hline Flavonoid & + & Terbentuk warna jingga kemerahan \\
\hline
\end{tabular}

Etanol Daun Baccaurea dulkis Muell. Arg

Keterangan $\quad: \quad(+) \quad:$ Terdeteksi

( - ) : Tidak terdeteksi 


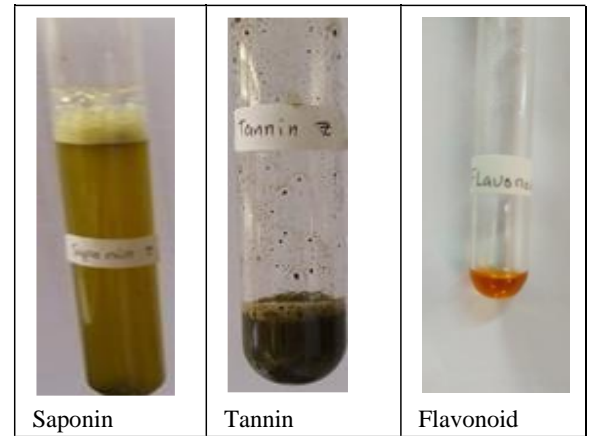

Gambar 1

Fitokimia Ekstrak Etanol Daun

Baccaurea dulkis Muell. Arg

Kelompok perlakuan diberi daun rambai dan pembanding diberi Povidone Iodin secara statistik terlihat adanya perbedaan yang bermakna pada tingkat $\mathrm{p}=0.05$, ini menunjukkan bahwa daun rambai dan povidone iodine memberikan pengaruh yang cukup baik untuk penyembuhan luka sayat.

Hasil penelitian terhadap kadar TGF- $\beta 1$ pada 25 ekor tikus yang mengalami luka sayat dari kelompok dapat dilihat pada tabel dibawah ini.

Tabel 2

Kadar TGF- 1 (pg/ml) Serum Tikus Yang Mengalami Luka Sayat Setelah Diberi Daun Rambai, Povidone Iodine Dan Aqudes

\begin{tabular}{llll}
\hline \multicolumn{3}{c}{ Kelompok } & \\
\hline No & Kontrol & Perlakuan & Pembanding \\
\hline 1 & 270.62 & 143.07 & 181.46 \\
\hline 2 & 203.75 & 207.46 & 266.90 \\
\hline 3 & 361.01 & 151.55 & 159.17 \\
\hline 4 & 394.44 & 199.75 & 203.75 \\
\hline 5 & 358.53 & 229.38 & 149.27 \\
\hline rerata & 317.72 & 186.24 & 192.11 \\
\hline
\end{tabular}

\section{B. Pembahasan}

Daun rambai telah digunakan untuk penelitian luka sayat pada hewan percobaan dan secara histologis menunjukkan bahwa daun rambai dapat meningkatkan penebalan epidermis, jalinan pembuluh darah serta meningkatkan jumlah kolagen dilapisan dermis dibandingkan dengan pemberian Aqudes. Mekanisme kondisi tersebut mungkin diantaranya disebabkan oleh pelepasan faktor pertumbuhan, sitokin, kemokin dan ekspresi dari molekul adhesi. Berdasarkan hasil penelitian terhadap kadar TGF- $\beta 1$ pada tikus luka sayat antara tikus kontrol yang hanya diberi aqudes.

Pada tabel di atas terlihat kadar dari TGF- $\beta 1$ bervariasi, ini mungkin menunjukkan bahwa setiap individu hewan tersebut mempunyai respon imunitas yang berbeda. Pada tabel diatas juga terlihat bahwa tikus yang diberi daun rambai 
kadar rerata TGF- $\beta 1$ sedikit rendah dibandingkan dengan Povidone Iodine secara statistik tidak menunjukkan perbedaan yang bermakna, tetapi jika kadar TGF-1 kelompok perlakuan dan pembanding tersebut dibandingkan dengan kelompok kontrol secara statistik terdapat perbedaan yang bermakna pada tingkat $\mathrm{p}=0.05$.

Namun antara kelompok yang diberi daun rambai dengan pembanding secara angka kadar TGF- $\beta 1$ terlihat ada perbedaan tetapi secara statistik tidak menunjukkan perbedaan yang bermakna. Penurunan kadar TGF- $\beta 1$ pada penelitian ini menunjukkan bahwa daun rambai mampu mempercepat fase inflamasi mungkin mengurangi infiltrasi dari monosit sehingga mempercepat fase-fase lain dari penyembuhan luka. TGF- $\beta$ diketahui berperan penting dalam inflamasi, angiogenesis dengan cara meningkatkan regulasi dari VEGF, reepitelisasi dengan meningkatkan proliferasi dari keratinosit dan regenerasi jaringan ikat. TGF- $\beta 1$ pada fase remodelling penyembuhan luka berperan dalam produksi kolagen. Pada kelompok yang diberi daun rambai pada luka sayat terlihat bahwa, daun rambai mampu mengangkat bekas luka atau keropeng pada tikus luka sayat tersebut. Ini menunjukkan bahwa daun rambai mungkin lebih cepat memperbaiki penyembuhan luka. Kondisi ini juga menyokong penelitian yang dilakukan oleh (Shuid, Yusof, \& Anwar, 2005) yang menemukan bahwa getah pepaya mampu membersihkan luka, mengurangi jaringan bekas luka pada tikus percobaan. Mekanisme membersihkan jaringan luka mungkin disebabkan oleh kemampuan papain untuk meningkatkan kemampuan sel- sel inflamasi untuk memfagositosis sel rusak disekitar luka, karena diketahui TGF- $\beta 1$ berfungsi untuk merubah monosit menjadi makrofag. Peran papain ini terhadap produksi dari faktor pertumbuhan tentu akan dapat membantu proses penyembuhan luka, namun tentu perlu penelitian lebih lanjut karena banyak faktor pertumbuhan dan sitokin yang terlibat dalam proses penyembuhan luka. Untuk itu perlu penelitian lebih lanjut tentang pengukuran kadar faktor pertumbuhan dan sitokin lainnya untuk memperkuat peran daun rambai selama penyembuhan luka.

\section{Kesimpulan}

Pemberian daun rambai pada tikus luka sayat lebih efektif dibandingkan dengan Povidone Iodine dilihat dari kadar rerata TGF- $\beta 1$ pada penyembuhan luka. Tidak terdapat perbedaan yang bermakna kadar rerata TGF- $\beta 1$ pada tikus luka sayat dengan penggunaan daun rambai dengan Povidone Iodine pada penyembuhan luka. 
Efektivitas Ekstrak Etanol Daun Rambai (Baccaurea Dulkis Muell.Arg) Terhadap Penyembuhan Luka Sayat dan Ekspresi Tgf-B1 Pada Tikus Putih Jantan

\section{BIBLIOGRAFI}

Dalimartha, Setiawan. (2008). 1001 Resep herbal. Niaga Swadaya. Google Scholar

Handayani, Hana, Feronika Heppy Sriherfyna, and Yunianta Yunianta. (2015). Ekstraksi Antioksidan Daun Sirsak Metode Ultrasonic Bath (Kajian Rasio Bahan: Pelarut Dan Lama Ekstraksi) [In Press Januari 2016]. Jurnal Pangan Dan Agroindustri, 4(1). Google Scholar

Hidayatullah, M. Dicky. (2016). Pengaruh Pemberian Infusa Sirih Merah Secara Topikal Terhadap Waktu Penyembuhan Luka Insisi pada Tikus Putih Jantan Galur Wistar. Fakultas Kedokteran (UNISBA). Google Scholar

Kanzaki, Tetsuto, Morisaki, Nobuhiro, Shiina, Ritsuko, \& Saito, Yasushi. (1998). Role of transforming growth factor- $\beta$ pathway in the mechanism of wound healing by saponin from Ginseng Radix rubra. British Journal of Pharmacology, 125(2), 255262. Google Scholar

Kee, Joyce L., \& Hayes, Evelyn R. (1996). Farmakologi. EGC. Google Scholar

Kumala Sari, Lusia Oktora Ruma. (2006). Pemanfaatan obat tradisional dengan pertimbangan manfaat dan keamanannya. Majalah Ilmu Kefarmasian, 3(1), 1. Google Scholar

Kurniawaty, Evi, Farmitali, Charla Gutri, Rahmanisa, Soraya, \& Andriani, Silvia. (2018). Perbandingan Tingkat Kesembuhan Luka Sayat Terbuka Antara Pemberian Etakridin Laktat Dan Pemberian Propolis Secara Topikal Pada Tikus Putih (Rattus norvegicus). Prosiding Seminar Nasional Pakar, 339-345. Google Scholar

Monaco, JoAn L., \& Lawrence, W. Thomas. (2003). Acute wound healing: an overview. Clinics in Plastic Surgery, 30(1), 1-12. Google Scholar

Muhammad, N. K. (2005). Antiseptics, iodine, povidone iodine and traumatic wound cleansing. Artikel Publikasi. Google Scholar

Perdanakusuma, D. S. (2007). Luka bakar pada perempuan hamil. Indonesian Journal of Obstetrics and Gynecology. Google Scholar

Prasetyaningrum, P. T. (2015). Uji Fitokimia Daun Rambai (Baccaurea motleyana Mull. Arg.). Poltekkes Kemenkes Pangkalpinang.

Shuid, Ahmad Nazrun, Yusof, Ahmad Asmadi, \& Anwar, Mohd Syukri. (2005). The effects of Carica papaya Linn. latex on the healing of burn wounds in rats. Jurnal Sains Kesihatan Malaysia (Malaysian Journal of Health Sciences), 3(2). Google Scholar

Sogandi, Sogandi. (2017). UJI Aktivitas Antibakteri Ekstrak Etanol 96\% Daun Rambai 
(Sonneratia Caseolaris,(L.) Engl) Terhadap Pertumbuhan Bakteri Escherichia coli. Indonesia Natural Research Pharmaceutical Journal, 2(1). Google Scholar

Sumara, Retno. (2017). Penggunaan Lumatan Daun Bunga Sepatu (Hibiscus RosaSinensis L) Untuk Penyembuhan Luka Insisi Pada Tikus Putih (Rattus Norvegicus Strain Wistar). Jurnal Keperawatan Muhammadiyah, 2(2), 66-71. Google Scholar

Tanjung, D. W. I. Haryanto1 Rosye H. R., \& Kameubun, D. A. N. Konstantina M. B. (2009). Pemanfaatan tumbuhan obat masyarakat Marind yang bermukim di Taman Nasional Wasur, Merauke. Google Scholar

Wang, Yan Hong, Avula, Bharathi, Nanayakkara, N. P. Dhammika, Zhao, Jianping, \& Khan, Ikhlas A. (2013). Cassia cinnamon as a source of coumarin in cinnamonflavored food and food supplements in the United States. Journal of Agricultural and Food Chemistry, 61(18), 4470-4476. Google Scholar

\section{Copyright holder:}

Zulfiawan, Kamaluddin, Irsan Saleh, Theodarus, Salni, fatmawati (2021)

First publication right:

Syntax Literate: Jurnal Ilmiah Indonesia

This article is licensed under:

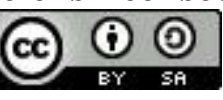

